\title{
Planning for a Strategic Guadalajara: Towards a Sustainable and Competitive Metropolis
}

\author{
Francisco Perez \\ Architect and urban planner, MA in Urban Design. Principal; FPA \\ Planning, Guadalajara. Former vice president of the International \\ Society of City and Regional Planners (ISOCARP).
}

\begin{abstract}
Increasing competition among cities, regions, and countries has moved public planning to developing strategies towards sustainable and competitive advantages. Francisco Perez, a planner based in Guadalajara, Mexico and State of Jalisco's former planning director, discusses the competitive advantages of Guadalajara's Metropolitan Area and the objectives behind the current strategic projects, including several he authored.
\end{abstract}

$D^{\text {sin }}$

eveloping productive cities is more feasible if it is based on identifying and exploiting their unique resources, characteristics, and capabilities: their comparative and competitive advantages. Once cities identify their advantages, they must develop strategic projects to exploit these advantages. These projects should have a comprehensive scope, an equitable benefit, and a sustainable result. Based on this hypothesis, this article describes the comparative and competitive advantages of Guadalajara, Mexico, and discusses nine strategic projects to exploit these advantages.

\section{Comparative and Competitive Advantages}

Nature itself shows us that ecosystems and the species that inhabit them are more successful in their evolution, survival, and development as they adapt themselves to the characteristics of the territory where they live. There are even some species that are the only ones to exploit certain advantages of their environment, finding minimal or no competition at all for those resources from other species.

By contrast, in the global world, except for some primary sector activities, it seems that all regions tend to produce as quickly as possible whatever the market demands, without much consideration of the characteristics and potential of the place where the cities are located. These cities concentrate on their ability to compete against a number of other cities that are eager to produce the same products. This makes the development of many regions of the world very uncertain and volatile, because it depends on external variables of the global capital and labor market which are difficult to predict and control.

Therefore for cities to advance solidly being very creative by constantly generating new development opportunities in an ever-changing environment is not enough -and often cities do so with great effort and considerable consumption of energy and resources. In this context, the idea of developing productive cities should be based on identifying and exploiting their comparative and competitive advantages.

The comparative advantage model is one of the basic concepts that justifies the theory of international trade. This model shows that countries and cities tend to specialize in the production and export of manufactured goods that they can produce at a relatively lower cost compared to the rest of the world, which makes them comparatively more efficient than others. ${ }^{1}$

On the other hand, competitive advantages are unique attributes of a city that give it the ability to achieve higher returns than other cities or regions in a sustainable way over time. This attribute must be unique because if competitors have it, it is not a competitive advantage. Moreover, a characteristic that is the basis of any competitive advantage should be appreciated by potential consumers. An advantage not perceived or valued by customers is not really an advantage. ${ }^{2}$

To make use of their advantages, cities must identify their potential resources and unique attributes. According to the UNDP definition, potential is defined as all those resources that exist in a given area, but that are not being fully utilized to enhance the level of sustainable human development. For UNDP, the potentialities go beyond the traditional concept related only to natural resources, considering a broader approach that includes as potential other factors linked to human, social, and cultural assets, as well as infrastructure and financial capital. According to UNDP, there are two types of potential: the tangible and the intangible. The former refers to physical investments such as utility infrastructure, infrastructure for production and /or transportation, natural resources, and financial resources. The latter refers to factors

\footnotetext{
1 See http://esepuba.files.wordpress.com/2009/03/david-ricardoprincipios-de-economia-politica-y-tributacion-cap-1-y-2.pdf; access 7/10/2013.

${ }^{2}$ See http://www.elergonomista.com/3ab12.html; access 7/10/2013.
} 
related to social capital, among which are: people skills (level of education, knowledge, and technology skills), forms of organization, and cultural and historical aspects. ${ }^{3}$

Comparative and competitive advantages of a city are better exploited by developing strategic projects. These projects will allow the organization, in a structured way, of those elements necessary for the successful use of unique resources. Strategic projects are defined in this article as those that meet the following characteristics:

- They should take advantage of the unique resources and aspects in a territory (location, natural resources, climate, economic structure, social aspects, cultural values, etc).

- Their development components should be well balanced and integrated: productive infrastructure and local economic development; protection and sustainable use of natural resources; social development and improvement of quality of life, etc.

- They must be identified through the analysis of local and global market opportunities.

Figure 1: Stategic projects in Guadalajara.

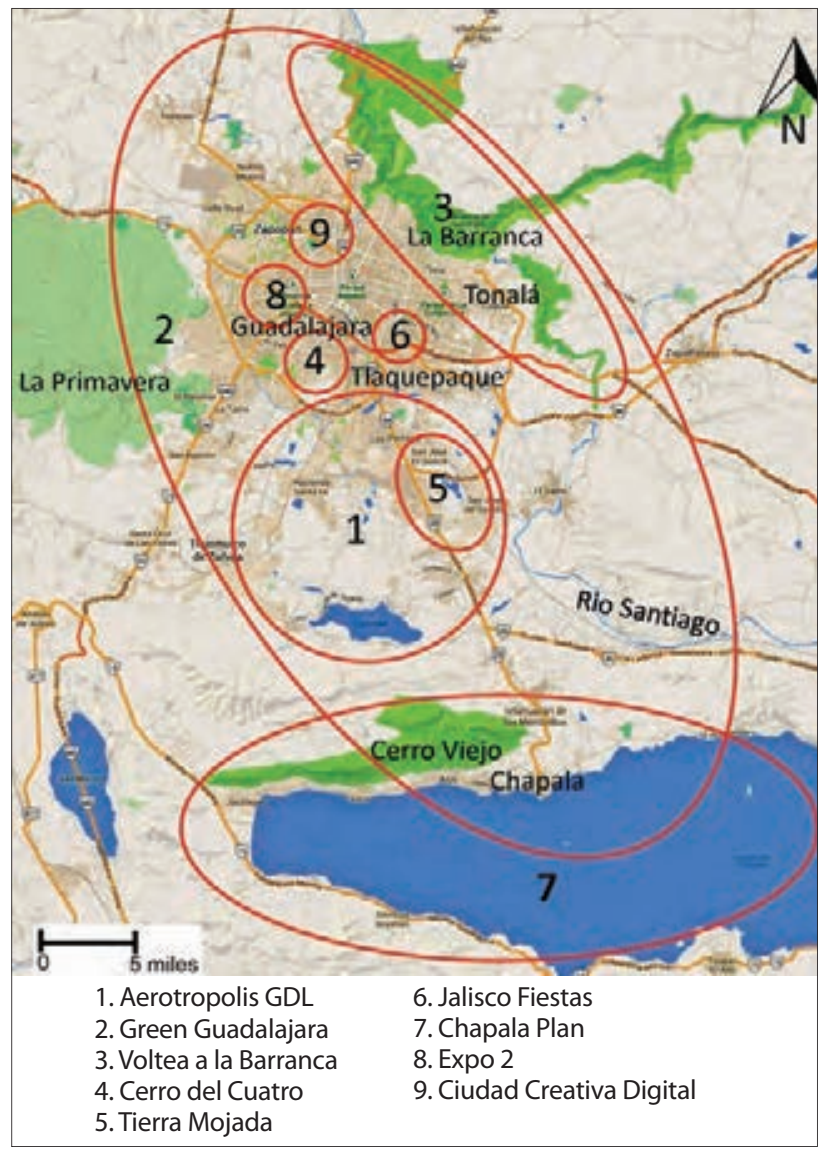

${ }^{3}$ See http://web.undp.org/spanish/latinamerica; access 7/12/2013.
- They must help structuring, ordering, and fostering urban development, materializing a city plan. We must consider that potentialities do not generate sustainable development by themselves unless they are part of a comprehensive territorial strategy leading to the rational use of the resources.

Within this framework, the purpose of this article is to describe the comparative and competitive advantages of Guadalajara Metropolitan Area and to present some strategic projects that would utilize these advantages (Figure 1). Among these projects, the first eight have been prepared or are being proposed by the author. The last project has been promoted by the government and the private sector. These projects address advantages that have not been exploited yet or should be better exploited, and are at various stages of development. Some are feasible in the short term and some of them are feasible in the middle or long term.

This presentation of potential projects does not include the kind of infrastructure and services that are essential for the day-to-day functioning of any city. Therefore, it does not include projects that are now a priority for Guadalajara, such as those related to supply and treatment of water, mobility, public transport, and public safety, among others.

\section{Advantage I: Location}

Located in the central west part of Mexico, Guadalajara was founded in 1542 with the purpose of serving as a strategic hub linking the capital of New Spain with the northwestern territories. From this foundational role the city, now has 4.5 million inhabitants and has become the country's second largest city. Guadalajara is not only a necessary step to reach the vast Mexican Pacific region but it has established itself as the center of Mexico's West Central Region that integrates eight states. It is the cradle of Mexican independence and is probably the country's most dynamic and productive region.

Figure 2: Guadalajara's location.

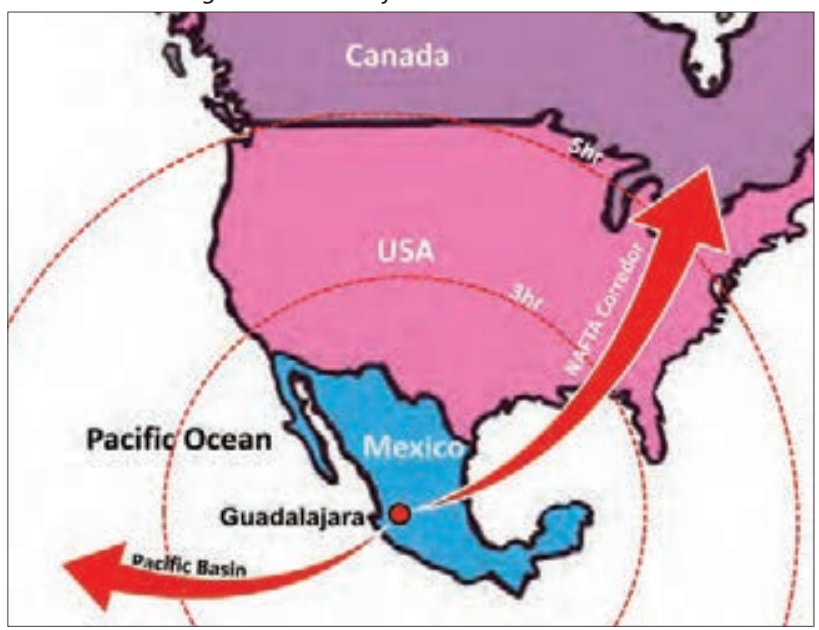


Located only 180 miles from Manzanillo, Mexico's largest port-Guadalajara is the Mexican metropolitan gate to the Pacific Basin and is a strategic link in the North America Free Trade Agreement corridor.

\section{Project 1: Aerotrópolis GDL}

Airports are magnets for new investment and they involve the development of areas between it and a city. These areas are key for economic development in many metropolitan areas, particularly in those where the airport is a strategic element for a city's progress and competitiveness. In today's competitive global market cities must have the ability to attract appropriate development to the area surrounding an airport: companies that depend on trade and air transport as well as multimodal logistic centers, multinational companies, research and development centers, trade, tourism, and other services.

A model called Aerotropolis has recently been developed; it combines airport planning, urban planning, and a business plan in a new urban concept that is highly attractive, competitive, and sustainable (Figure 3). ${ }^{4}$ Guadalajara International Airport is Mexico's second most important and due to its location and historical role, the city functions as a regional and mesoregional hub. This is an important competitive advantage to be seized. The airport's development potential itself and that of its surrounding area is huge, and could become one of the most important districts in Guadalajara's Metropolitan Area. ${ }^{5}$

Presently the airport is not conveniently connected to the city and the metropolitan area. There is no comprehensive development plan for the airport area and the urban sprawl has reached its current limits, threatening the area's future growth

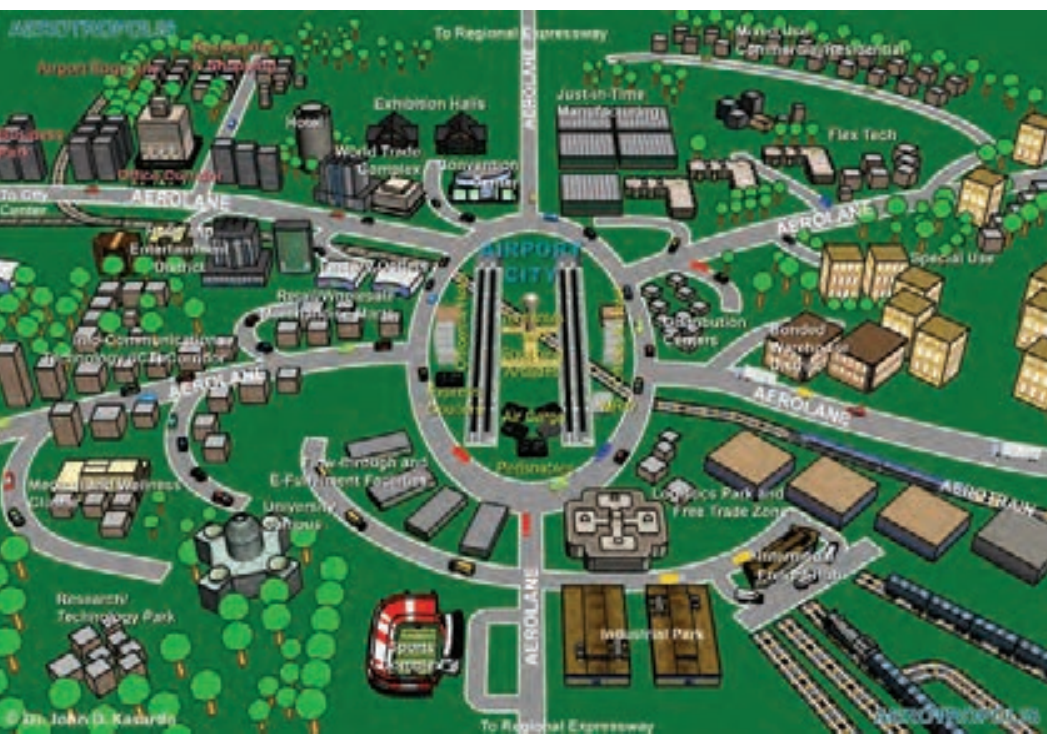

\footnotetext{
${ }^{4}$ See http://www.aerotropolis.com; access 7/12/2013.

${ }^{5}$ See http://www.aeropuertosgap.com.mx/aeropuertos/guadalajara; access $7 / 12 / 2013$
}

possibilities. Recent sprawl in the municipality where the airport is located, based on social housing, has brought more problems than benefits to this area, wasting the potential to attract sources of productive employment and development.

The trend scenario is one of chaotic sprawl, decay, and strangulation of the airport, with the consequent deterioration of service and loss of competitiveness. Among other things, this degrades the actual experience of airport concession for a private company. Facing this scenario, none of the three levels of government (federal, regional and local), nor the airport concessionaire, has made effective efforts to alleviate the problems of this area.

On the contrary, the desired scenario is one that solves the environmental and social problems of the area, leading to orderly growth and the promotion of productivity. This would ensure the future development of the airport itself and the improvement of the service in a more competitive framework, presenting a successful model to follow. Achieving this scenario is the aim of promoting Aerotrópolis GDL.

The overall objective of the Aerotrópolis GDL initiative is to put forward a solidly supported vision for the future, with a portfolio of projects to promote the integrated action of federal, state, and municipal governments, the airport concessionaire, and business sectors and social groups involved in the area. Its specific objectives are to:

- Ensure the necessary reserves for the airport's growth.

- Define the necessary infrastructure for both the airport and the development of the area in terms of roads, transportation, sewage collection and treatment, and storm drainage, among others.

Figure 3: Aerotrópolis conceptual layout. Source: Dr. John D. Kasarda.

Figure 4: Aerotropolis GDL area within the metropolitan framework. Source: Metropolitan Region Master Plan.

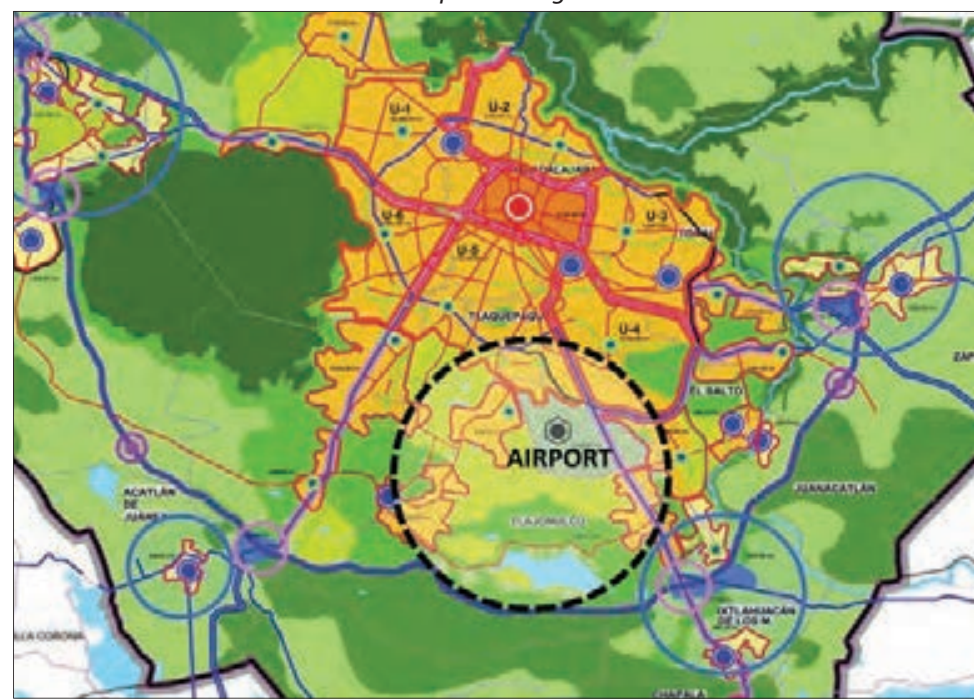


- Convert the area into a strategic district of Guadalajara Metropolitan Area.

- Solve current environmental problems and risks.

- Design gears for coordination, management, financing, participation, and monitoring.

- Consolidate the airport as a first-level regional hub.

- Promote competitive complementary uses.

A portfolio of ten projects aims at implementing these goals (Figure 5). Aerotrópolis GDL is a huge long-term project still at its first stage of promotion. It requires vision, planning, and consensus on a large scale, as well as short-term actions to address the priority needs. This project is of regional interest, needs to be part of the state government's strategic agenda, and requires strong support from the federal government. It is essential to involve private investors, landowners, and all stakeholders. Financing requires substantial government investment in basic infrastructure but most of the resources will certainly be generated from having an attractive business portfolio, internationally financed.

\section{ADVANTAGE II: NATURAL RESOURCES}

Mexico is one of the most biologically diverse countries in the world; Jalisco is one of the states with the greatest biodiversity in Mexico and its capital, Guadalajara, is the most biologically diverse region of Jalisco. It has even been described as "the biological synthesis of Mexico". This rich biodiversity is due mainly to Guadalajara's location at the confluence of Sierra Madre Occidental, Sierra Madre del Sur, and Eje Neovolcánico.

Moreover, the city is located on vast and productive valleys of moderate topographic slope at approximately 4,500 feet above sea level. It is flanked to the northeast by La Barranca --the Santiago River Canyon-- which runs 3,000 feet above sea level, and by La Primavera Forest to the west, which rises 6,000 feet above sea level. This allows the metropolitan area to have more ecosystems than many countries in the world.

Another strategic advantage is the kindness of the prized temperate climate, averaging $70^{\circ} \mathrm{F}$. This allows not only the comfort of its inhabitants most of the year, but minimum energy consumption for heating and cooling.

\section{Project 2: Green Guadalajara, or Guadalajara Verde}

It has been said that Guadalajara is located in a privileged natural environment. Unfortunately it must be recognized that the city has not exploited this competitive advantage to make it a better place to live. In contrast, among the problems faced are: threatened natural areas, a deficit of green areas, infill of natural waterways, erosion, loss of groundwater infiltration, diminishing aquifers, and increasing air pollution.

It is therefore essential to promote a green vision for the city, to reverse the prevailing problems and take advantage of the

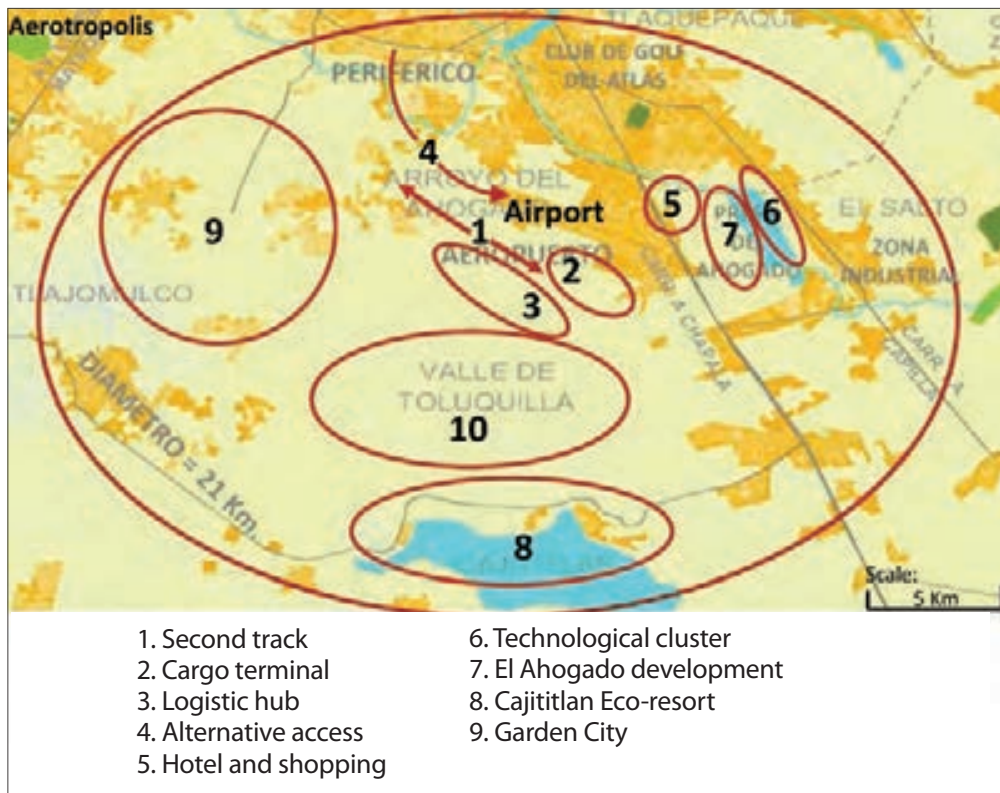

Figure 5: Strategic projects to support Aerotropolis GDL.

existing potential in a sustainable way. For such, it is important to pursue the following environmental objectives:

- Reforestation of 2,400 acres. This will increase green areas by two square meters per inhabitant.

- Conversion of $\mathrm{CO} 2$.

- Rainwater infiltration and soil retention.

- Social objectives:

- Increasing equity and social integration.

- Supporting sports and health.

- Promoting environmental and botanical education.

- Urban objectives:

- Improving urban image and identity.

- Raising quality of life.

- Promoting ecotourism.

These objectives will be achieved through the following 10 programs (Figure 6).

\section{Protected Natural Areas.}

La Primavera, a 72,000-acre forest, is the most emblematic protected natural area in metropolitan Guadalajara. The main benefits it brings to the city are clean air and water. However, the forest is constantly threatened by urban growth, and every year during the dry season it suffers from numerous fires. Although there is a decree for its protection and there is an agency for its management, the official support has been minimal. On the other hand 23,000 hectares in Cerro Viejo have also been recently declared protected natural area, and the 
Santiago River Canyon (La Barranca) Act is to be signed soon, protecting another 52,000 hectares.

These three protected natural areas alone account for more than 240,000 acres. However, it is not enough just to enact these areas as protected. It is necessary to ensure their proper management and the financial resources to do so, mainly through a charge for environmental services. All this is to be promoted through a metropolitan program for the management of protected natural areas.

\section{Green Boundaries.}

It has been mentioned that La Primavera Forest is heavily pressured by speculation and urban sprawl, especially at the metropolitan edge. Meanwhile La Barranca has suffered the disdain of the city, which has turned its back over the years. In both natural areas, a public property edge must be generated to allow the final demarcation of urban growth, and to allow public transit to ensure security, firefighting, and public access to all citizens. These green edges extend to 25-mile wide in La Primavera Forest and 38-mile wide in La Barranca; they will be as wide as circumstances permit, at least allowing free transit. These strips would be transferred to public ownership as part of prospective urban developments on vacant land or through gradual public acquisition.

Figure 6: Location of Green Guadalajara programs.

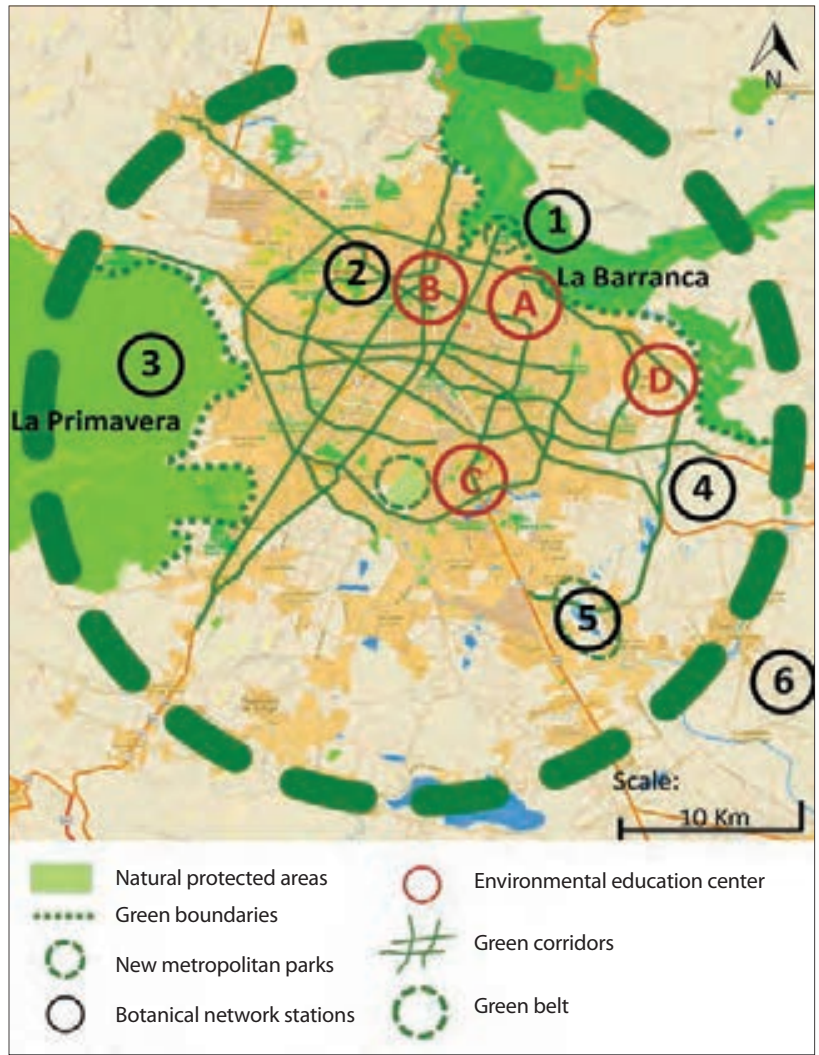

\section{New Metropolitan Parks.}

In Guadalajara there are only three large urban parks with an average area of 240 acres each. There is a deficit of green areas, particularly in low-income sectors. The Green Guadalajara initiative includes the promotion of three large parks at a metropolitan scale: La Barranca Botanical with 840 acres hectares, Cerro del Cuatro with 360 acres, and El Ahogado with 960 acres. These three large parks provide a substantial public green area for three urban districts with significant environmental and social problems. They are the central pieces of three strategic projects presented in detail below.

\section{Botanical Network.}

A botanical garden is in the process of consolidation at La Barranca. However, the botanical wealth of metropolitan Guadalajara offers the possibility to present at least seven ecosystems where a large range of plants live in their natural environment: 1. gallery deciduous forest in La Barranca itself, 2. springs in Los Colomos, 3. pine-oak forest in La Primavera, 4. thornscrub in Tonala, 5. wetlands in el Ahogado, 6. riparian ecosystem in Los Sabines stream, and 7. lake ecosystem in Chapala Lake (see location in Image 8). Seven botanical stations can operate in these places in an integrated botanical network, presenting a unique alternative for specialized tourism; in a couple of days, visitors can enjoy seven completely different botanical communities in their natural state. These stations would include botanical education centers, recreational activities, and services.

\section{Environmental Education Network.}

A city cannot become sustainable only by decree or good will. It needs informed, educated, and engaged citizens. Therefore, environmental education is essential to build a sustainable culture. Green Guadalajara includes a series of environmental education centers. Reflecting the characteristics of their location, the focus at each place will be the particular urbanenvironmental issues facing Guadalajara. A) In La Barranca, as the most bio-diverse area of the city, the focus will be natural resources. B) In Los Colomos, where the first source of piped water for the city is located, the theme will be water. C) In Cerro del Cuatro, where the highest air pollution in the city is recorded, the topic will be air and rational energy use. D) The Matatlán landfill will be remedied, turning it into a public park, and the focus will be recycling and management of solid waste.

\section{Green Corridors.}

While the per-capita deficit of green areas is increasing, this city-once appreciated for its parks and gardens-has been "forested" with an impressive number of humongous billboards along its avenues, burying the ancient and famous image of Guadalajara as "The Pearl of the West "and "The City of Fountains and Roses". In addition, most of the city's natural streams have been filled in or channeled, with the consequent 


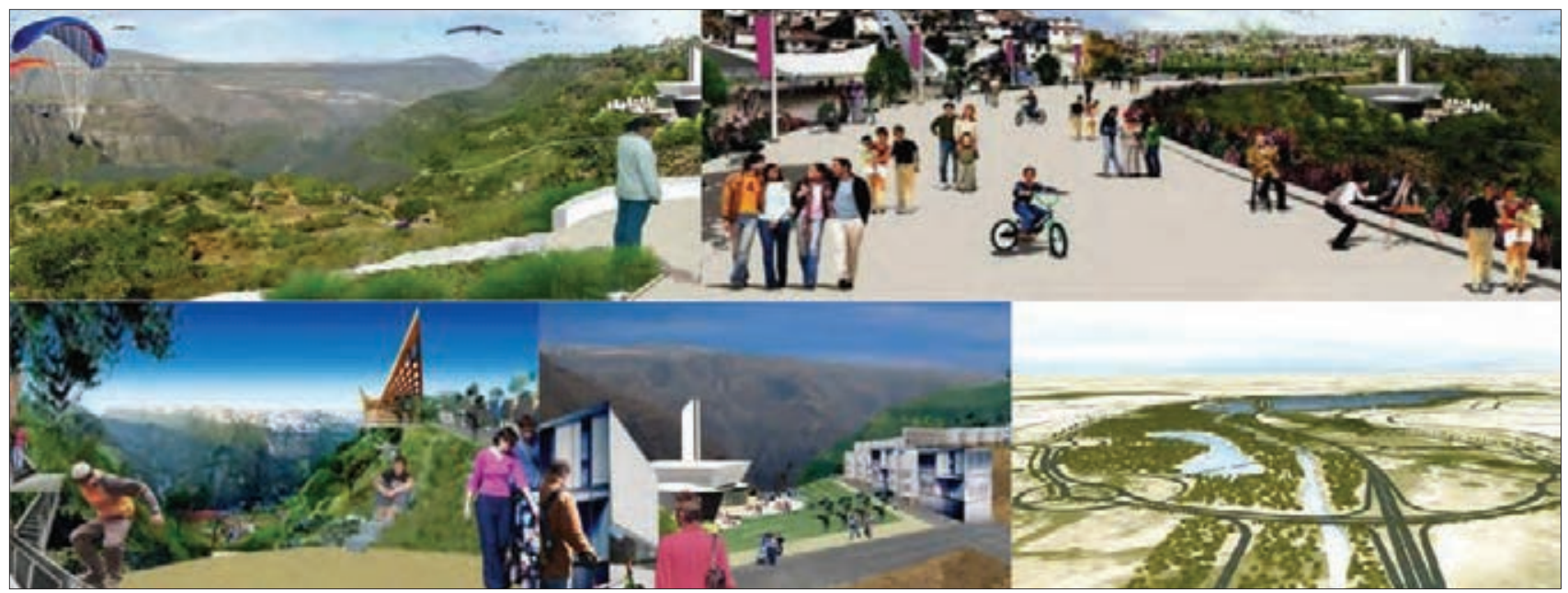

Figure 10: Voltea a La Barranca conceptual renderings.

a new symbol of the metropolitan area. The 360 -acre park sits at the top of the hill and will be surrounded by a ring road on its lower level for allowing full accessibility to the park and an important concentration of urban facilities around it (Figure 12).

The park will offer a wide range of activities at the regional, metropolitan, urban district, and neighborhood levels, to attract as many people as possible. A number of attractions will be located on the hillside, such as extreme sports, leisure, and other economically productive activities to attract tourism, generate jobs, and make the park operation self sufficient. The major attraction will be at the hilltop, with a sky-view resort, a monumental antenna, and an open forum, accessible by road and cable car. A first phase of the park has already being built, and efforts are underway to incorporate developers of neighboring private empty land into the project.

\section{Project 5: Tierra Mojada}

The Tierra Mojada -which means wet soil- project will transform an area with severe environmental and urban problems in the heart of the airport district and the Aerotropolis GDL project. It is located at the end of the metropolitan area's largest water basin which suffers from pollution of its soil, its surface water, and its groundwater. A wastewater treatment plant has just been built next to the reservoir but not all sewage generated in the basin is connected to the system yet.

The 2,000-acre area to be developed is currently occupied by the El Ahogado dam and reservoir (Figure 13). Built more than 100 years ago to provide water for irrigation the dam is now used for flood control. The area has been progressively occupied by irregular settlements that get constantly flooded with the communities exposed to unhealthy conditions, and the area suffering from environmental degradation. Nevertheless, the area is strategically located next to the airport, very well connected by two major regional-metropolitan roads with all needed infrastructure in place, and very close to a vast job market generation.
The area is planned to develop and operate almost as a selfsufficient small city, with all required land uses and public services. It includes: 530 acres of water bodies, 480 acres dedicated to housing, 96 acres for public facilities, 480 acres for green areas and open spaces, 216 acres for shopping, services, and leisure, and 240 acres for a technology cluster. Due to the advanced construction phase of the wastewater treatment system, the project might start development soon.

\section{ADVANTAGE III: TRADITIONS}

Although Mexico enjoys a rich cultural mosaic across its territory, the state of Jalisco and its capital Guadalajara are the cradle of the traditions that have given Mexico its image around the world. Among these traditions from Jalisco, tequila, mariachi music, and the wide charro hat are unequivocally Mexico's distinctive image in every corner of the planet.

Figure 11: General concept for Cerro del Cuatro.

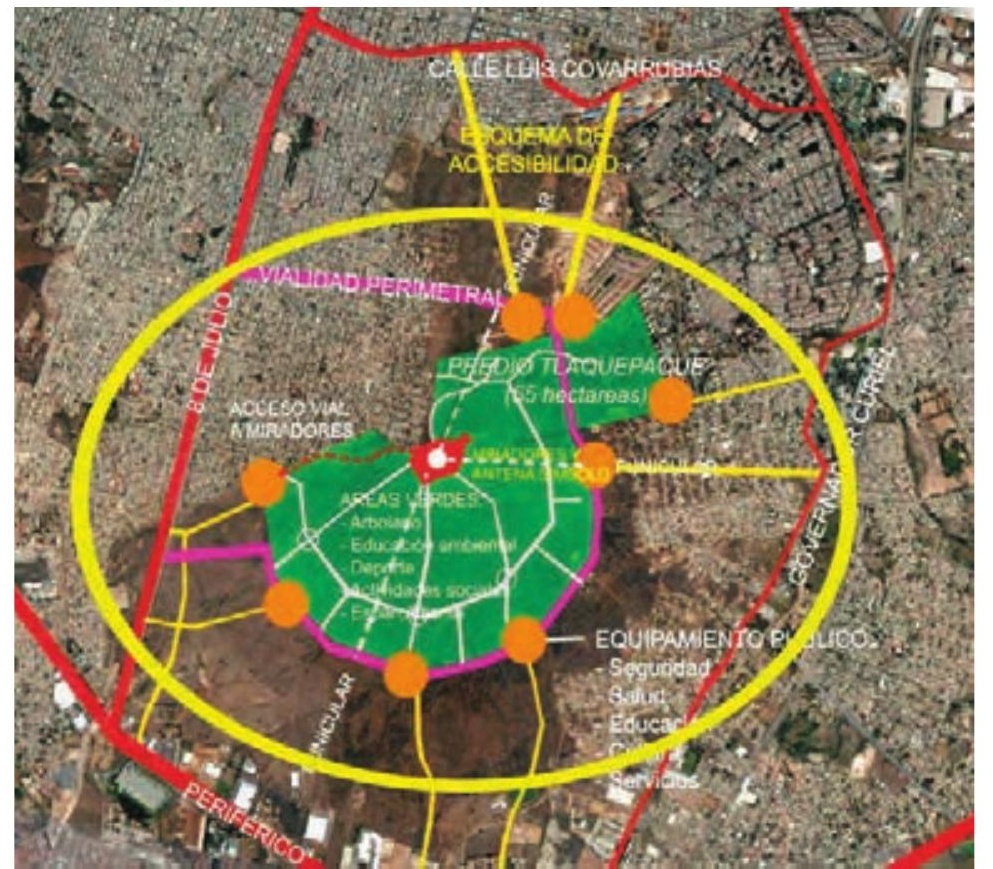




\section{Handicrafts Fiesta.}

The existing and almost forgotten Jalisco's Handicrafts House will be relocated here to show the vast diversity of production in the state, including among others: blown glass from Tlaquepaque, Tonala pottery, equipales from Zacoalco, piteado from Colotlán, cutlery from Sayula, bone manufacturers from Teocaltiche, and Huichol handicrafts. A crafts school will be established for classes, conferences, and workshops, and an annual International Handicrafts Fair will be held.

\section{Folklore Fiesta.}

The area will house the Folklore Museum of Jalisco, a folk dance school, and an auditorium for the Ballet Folklorico de Guadalajara. An annual International Folklore Meeting will be hosted.

\section{Gastronomic Fiesta.}

The Gastronomic Parian (court) will be the epicenter of Fiestas de Jalisco, where visitors will enjoy all sorts of Jalisco's tasty dishes, while toasting with tequila and being entertained with mariachi music. There will also be a museum, a school and food market, and an annual Festival of World Cuisine. Additional activities and facilities will be included, such as traditional Fiestas de Octubre, a shopping center, hotels, an amusement park, and a tourist tram circuit to Tlaquepaque.

Still in its promotional phase, the Fiestas de Jalisco project will expand Guadalajara's and Jalisco's visibility around the world, strengthening city and regional tourism and cultural activities, and help preserve and promote local traditions.

\section{ADVANTAGE IV: CHAPALA}

With an area of approximately 420 square miles, Chapala Lake is Mexico's largest freshwater lake. Surrounded by seven municipalities in the states of Jalisco and Michoacan it is part of the country's most important watershed and has great environmental significance. Chapala Lake supplies the Guadalajara Metropolitan Area with 60 percent of its drinking water. It has recently been declared a Ramsar site, as a wetland of international importance. ${ }^{6}$ The lake offers great potential for development of fisheries and agriculture, and especially for tourism, mainly housing, accommodation, and services for large foreign retirement communities.

Located sixteen miles from the international airport and 31 miles from Guadalajara's historic center, Chapala has been a traditional tourist site since the beginning of the last century. It has been an attractive place for foreign retirement, and in the 1950s it became one of the most popular places of the kind. These retirees are mostly U.S. and Canadian citizens, although

\footnotetext{
${ }^{6}$ See http://www.ramsar.org/cda/es/ramsar-news-archives-2011-mexico-jaguey/main/ramsar/1-26-45-489\%5E25262_4000_2_; access 7/12/2013.
}

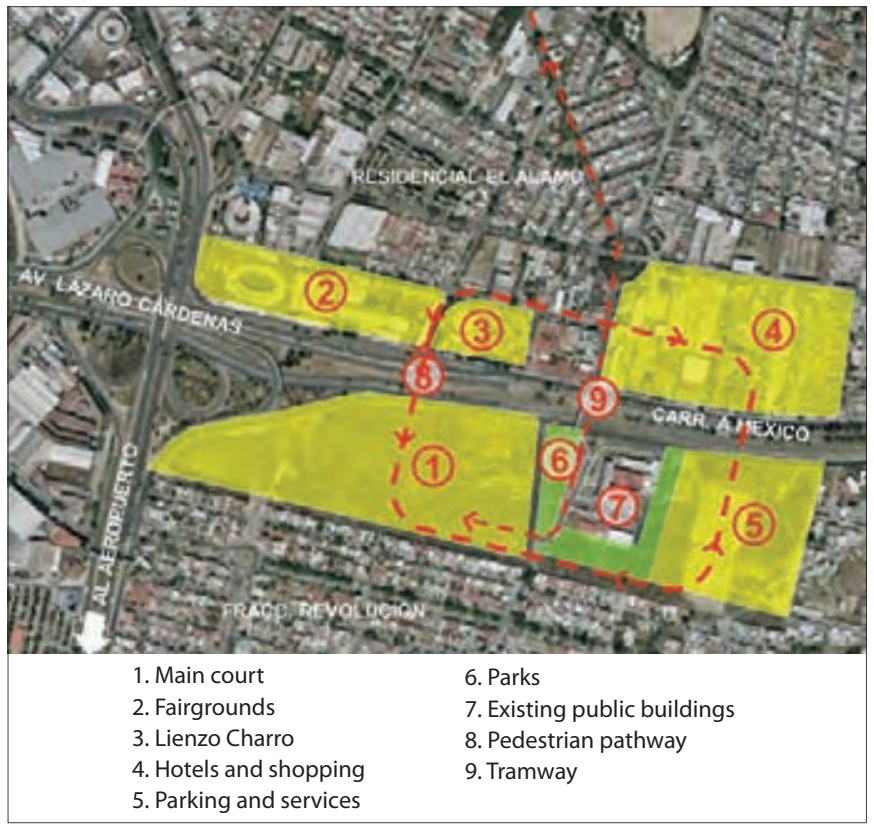

Figure 14: Fiestas de Jalisco conceptual layout.

the foreign community is comprised of more than twenty nationalities. ${ }^{7}$ As the area is well known, this market is rapidly increasing and offers enormous potential for the region.

\section{Project 7: Chapala Plan}

In spite of its importance and potential, in recent years Chapala Lake has been heavily threatened by excessive water extraction, land invasion into the lake, wastewater discharges, pollution, and disorderly urban growth, especially along the Chapala-Jocotepec corridor. In the face of these problems, only very limited isolated, short-term action has been taken without really meeting the area's requirements, and without a comprehensive action plan to sustainably utilize the great potential of the area in the long term.

The restoration and development of the country's largest lake, shared by two states of the federation, is undoubtedly a national priority and requires the full support of the federal government, but should be promoted by the government of Jalisco, the most significant stakeholder in the tributary basin. This program should be supported firmly by social and private sectors. It should be based on a comprehensive development plan to drive the improvement, management, promotion, and full development of the area.

The plan must not only consider solutions for the current problems in the area, but must also include a vision for the future. The vision must be as ambitious as the great potential of this region allows, and must be as sustainable as the environmental fragility of the area requires. It should be an

\footnotetext{
${ }^{7}$ See http://www.lakechapalasociety.com; access 7/10/2013.
} 


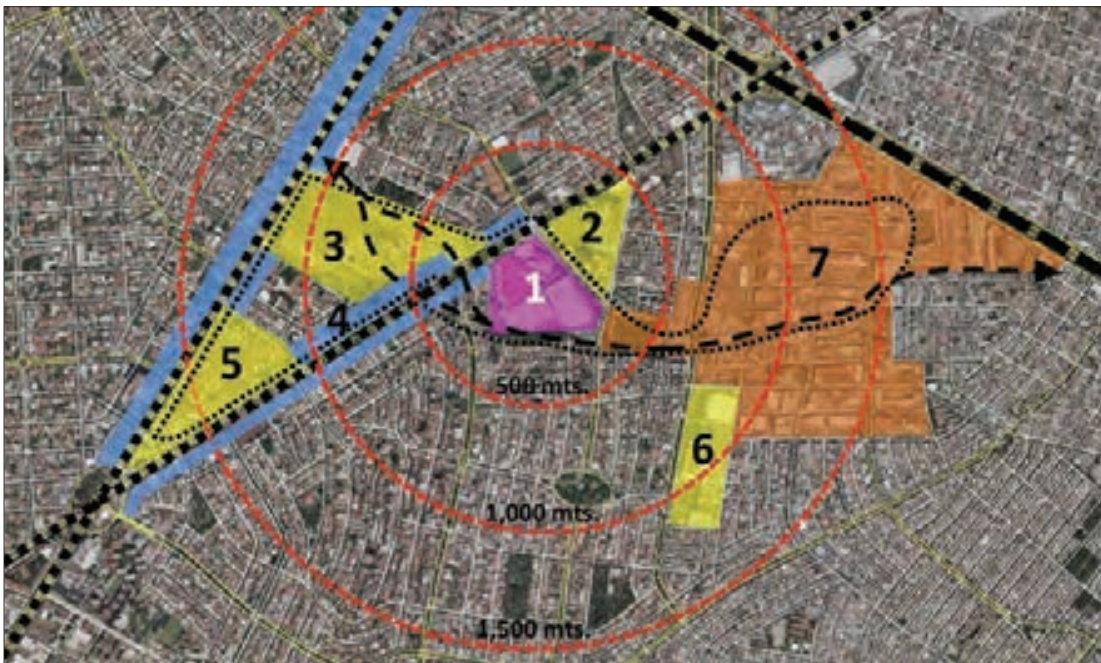

Figure 15: EXPO 2.

1. Expo Guadalajara

2. World Trade Center

3. Mixed use development

4. Hotels and shopping corridor

5 and 6 . Shopping malls

7. Area for redevelopment

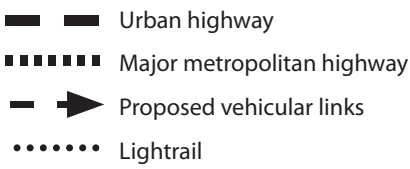

integrated vision for the long term, with concrete actions to be carried out in the short term. Chapala Plan will be the tool to achieve the following goals:

- Total cleaning and hydrological sustainability of the lake.

- Environmental protection.

- Total restoration of federal lands and sustainable use of areas where no environmental impact will occur.

- Consolidation of Chapala as the largest foreign community of U.S. and Canadian citizens outside their respective countries.

- Greatest levels of sustainable fishing and agriculture.

\section{ADVANTAGE V:TOURISM}

Given its location, climate, wide availability of shopping and services, and the diversity of available attractions, Guadalajara is a major tourist center in the region, with more than 22,000 hotel rooms available. Business tourism is particularly relevant. A number of important national and international events take place in various venues in the city. Expo Guadalajara alone has 1,2 million square feet and claims to have generated an economic impact in 2011 of about 7,000 million (7 billion) pesos. $^{8}$ It is the largest and most important fair and exhibition center in Mexico. Among the most relevant exhibitions held here each year is the International Book Fair, the world's largest Spanish language book fair.

\section{Project 8: EXPO 2}

Expo Guadalajara is located in an area that concentrates a large amount of hotel rooms and square meters of shopping. The area is heavily congested by vehicular traffic, and is already close to its full land-use capacity. The only available neighboring land is about to be developed into a large mixed-

\footnotetext{
${ }^{8}$ See http://www.expo-guadalajara.com; access 7/10/2013.
}

use complex. This means expansion of the exhibition activities in this area is already quite curtailed.

On the other hand, behind Expo Guadalajara is an extensive area with a gloomy future. This is the once-flourishing regional food market, an area where tons of perishable food were traded every day by merchants from a quite vast region of western Mexico. The evolution of the perishable food trade in recent years - with large warehouses no longer needed-has already left many hectares of underutilized land in this place. It is Interesting to note here this area developed successfully at a time when the regional circumstances gave the city a comparative advantage that does not exist anymore.

The Expo 2 project proposes gradually redeveloping this former food market area into a modern extension for congresses, fairs, and exhibitions, together with hotels, shopping, services, and, of course, housing (Figure 15). Additionally, the current Expo area would be linked directly to the most important freeway connecting to the airport and the rest of the metropolitan area.

\section{ADVANTAGE VI: KNOWLEDGE ECONOMY AND CREATIVE INDUSTRY}

Mexico is producing television, movies, and cultural programs watched by more than one billion people in more than one hundred countries. It is an emerging global leader in the creative industry and it is becoming a destination for content creation. International companies see Mexico as a step into the rapidly expanding Latin American market.

CANIETI (National Chamber of Electronics, Telecommunications and Information Technologies) started promoting a digital cluster in Mexico and, with help from the Massachusetts Institute of Technology (MIT), searched for the best place for the Ciudad Creativa Digital (CCD) or Creative Digital City. This cluster will enhance Guadalajara's competitive advantages to compete in the knowledge economy and the creative industry, 
particularly because the city already offers:

- Rapid access to all of Mexico and the United States through 3 to 5 -hour flights.

- More than twenty universities offering many disciplines, including engineering, applied sciences, and arts.

- An important high-tech community and is known as Mexico's Silicon Valley, since it is an IT national leader with the country's largest tech cluster and more than 600 specialized companies.

- One of Mexico's most successful software incubation facilities.

\section{Project 9: Ciudad Creativa Digital}

In CANIETI's initiative a dozen cities in the country were assessed across multiple aspects including macro-economics, environmental quality, industrial base, and development potential. Guadalajara was chosen as the best place to locate the Ciudad Creativa Digital because of its comparative advantages. The CCD will occupy more than 96 acres of public land in the heart of Guadalajara, leading to the revitalization of approximately 1,100 acres of the historical center. CCD will become a hub for the digital media industry including TV, cinema, advertising, videogames, digital animation, interactive multimedia, and e-learning (Figure 16).

CCD is now in its formative and promotional phase with the full collaboration of CANIETI and the federal, state, and municipal governments. CCD will attract Mexican and foreign creative professionals and will enhance Guadalajara's natural position as a global creative leader. At its maturity CCD will employ an estimated 10,000 digital creative professionals and provide for a population of approximately 50,000 people.

\section{FINAL REMARKS}

There are no doubts that Guadalajara is a city well favored by a wide range of unique resources, characteristics, and capabilities that shape its comparative and competitive advantages and offer enormous potential for development. It is evident that the city has not yet done enough to exploit this potential and in many cases is wasting and deteriorating that potential. This seems to be because the decision makers do not have enough knowledge and analysis of the area and of the city itself, and because decisions about city development are heavily influenced by the strong synergy of the global market.

Additionally, important strategic projects aligned with the city's advantages are not easily undertaken because many are longterm enterprises. It does not fit within the short-term view of governments that focus on the immediacy of short political administrations and entrepreneurship expectations that seek secure and fast returns. In any case, it is clear that there is a lot that can be done to fully exploit Guadalajara's competitive and comparative advantages to their full potential, but unfortunately there is no clear strategy to do it.
Figure 16: The CCD setting in Guadalajara's historic core. (From MIT Senseable City Lab. http://www. carloratti.it/FTP/CCD/files/CCD brochure.pdf)

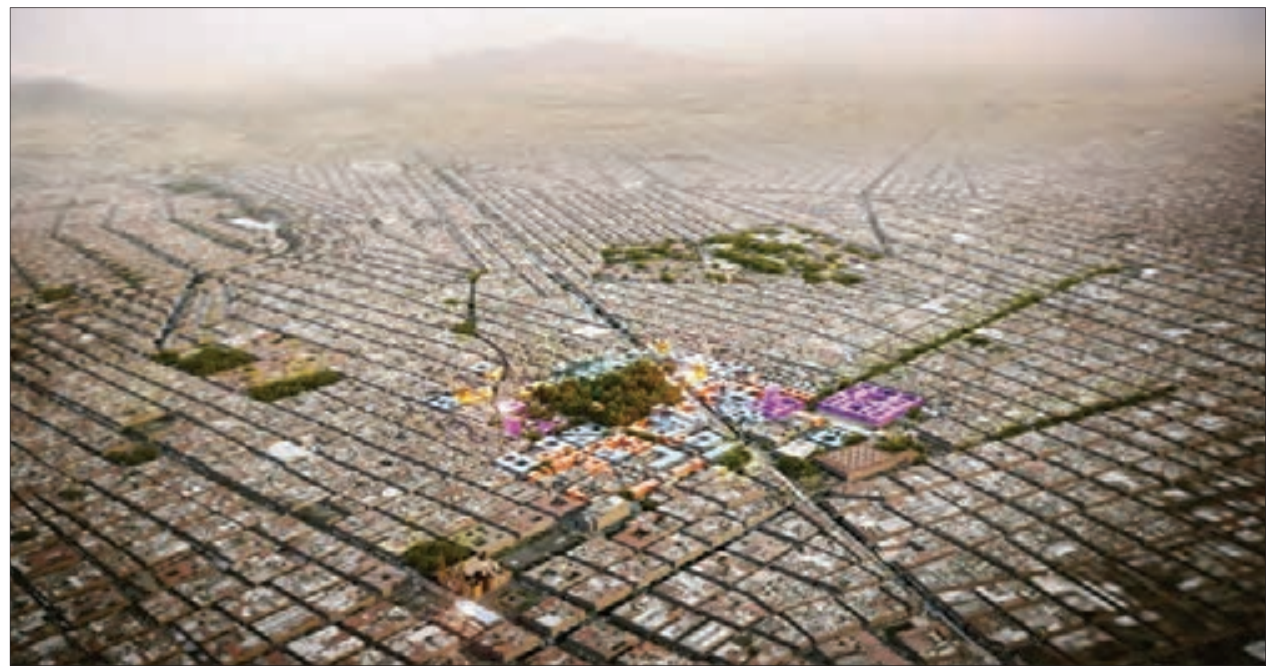

